\title{
KS. HENRYK MISZTAL
}

\section{SPRAWA BEATYFIKACJI MICHAEA GIEDROYCIA}

Spotykamy się ostatnio (zwłaszcza po wydaniu nowego ustawodawstwa papieża Jana Pawła II) z dość skrajnym poglądem, iż należy zarzucić wszelkie starania o beatyfikację czy kanonizację tych osób, które cieszą się legalnym starożytnym kultem i które od wieków są nazywane „błogosławionymi” lub „świętymi”, lecz dotychczas nie zostały formalnie czy równoznacznie beatyfikowane. Tymczasem konstytucja apostolska Divinus perfectionis Magister z 25 I 1983 r., traktując o dochodzeniach prowadzonych przez biskupów, podaje: „Biskupom diecezjalnym lub hierarchom $\mathrm{i}$ wszystkim $\mathrm{z}$ nimi zrównanym $\mathrm{w}$ prawach $\mathrm{w}$ zakresie ich jurysdykcji, czy to $\mathrm{z}$ urzędu, czy na prośbę poszczególnych wiernych lub prawnych związków i ich pełnomocników, przysługuje prawo przeprowadzania dochodzeń na temat życia, cnót lub męczeństwa i opinii świętości lub męczeństwa, faktów przyjmowanych za cudowne i, jeśli zachodzi taki przypadek, starożytnego kultu sługi Bożego, o którego kanonizację się prosi" (I 1$)^{1}$. Zatem konstytucja apostolska nie tylko nie zakazuje takich starań, ale też je wprost i bezpośrednio przewiduje, czyli tym samym dopuszcza.

Realizacją tej dyspozycji konstytucji apostolskiej jest przepis zawarty w Normach Kongregacji Spraw Kanonizacyjnych, które należy zachować przy przeprowadzaniu dochodzenia przez biskupów w sprawach kanonizacyjnych, który brzmi: „W sprawach dawnych pytania dotyczą jedynie aktualnej opinii świętości lub męczeństwa i kultu oddawanego słudze Bożemu w czasach nowych, jeśli taki ma miejsce" (N. 15, b) ${ }^{2}$.

Jeśli chodzi o kompetentnego biskupa, który ma się zając przeprowadzeniem dochodzenia, to wspomniane Normy mówią o biskupie, „na którego terytorium sługa Boży zmarł, chyba że okoliczności szczególne, zaaprobowane przez kongregację, wskazywałyby co innego" (N. 5, a) ${ }^{3}$. Nie ulega więc wątpliwości, iż sprawę mógłby prowadzić także biskup diecezjalny, na którego terytorium istnieje starożytny kult ,świętego" lub ,błogosławionego".

1 Sacra Congregatio pro Causis Sanctorum. Novae leges pro causis Sanctorum, Typis Polyglottis Vaticanis 1983, s. 5-6.

2 Tamże, s. 13.

Tamże, s. 11 . 
W odniesieniu zatem do interesującej nas sprawy beatyfikacji Michała Giedroycia możemy wstępnie ustalić, iż nie tylko wolno się nią interesować, ale także możemy twierdzić, że kompetentnym do jej ewentualnego prowadzenia będzie metropolita krakowski.

W ,sprawie beatyfikacji Michała Giedroycia” chodzić nam będzie o ustalenia formalno-prawne, a nie historyczne. Dla jaśniejszego przedstawienia problemu należy mówić przynajmniej o dwóch kwestiach: stwierdzenia legalności kultu błogosławionego Michała przez miejscowego biskupa i konfirmacji tegoż kultu przez Stolicę Apostolską, czyli beatyfikacji równoznacznej. Z tymi kwestiami łączy się także problem ewentualnego rozszerzenia kultu lokalnego poprzez uzyskanie indultów mszy i oficjum własnego o błogosławionym. Zatem możemy tu mówić o dwóch etapach: (1) administracyjny - poprzedzony badaniami naukowymi i zakończony dekretem biskupa na temat legalności kultu, (2) sądowy - zdążający do potwierdzenia tegoż kultu przez Stolicę Apostolską.

\section{STWIERDZENIE LEGALNOSCI KULTU BEOGOSŁAWIONEGO MICHAEA}

Papież Urban VIII (1623-1644) dekretem Kongregacji Inkwizycji z 13 III 1625 r., potwierdzonym przez konstytucję apostolską Caelestis Hyerusalem cives z 5 VII 1634 r., zabronił oddawania kultu publicznego osobom zmarłym $\mathrm{w}$ opinii świętości, a nie beatyfikowanym lub kanonizowanym przez Stolicę Apostolską ${ }^{4}$.

Biorąc pod uwagę dobro spraw prowadzonych drogą kultu, Urban VIII w obu wspomnianych aktach prawnych uczynił wyjątek zwany „wypadkiem wyjętym" (casus exceptus). Pozwolił mianowicie na pozostawienie kultu publicznego w odniesieniu do tych zmarłych, którzy odbierali go od niepamiętnych czasów lub na podstawie ogólnej zgody Kościoła, albo też kult ich wynikał z pism Ojców Kościoła i świętych pisarzy, bądź też byli czczeni za wiedzą i tolerancją Stolicy Apostolskiej lub ordynariuszy ${ }^{5}$. Źródła ,wypadku wyjętego" znajdujemy już w dekrecie papieża Klemensa VIII z 7 VIII 1596 r., gdzie zapisano słowa: „Nie chcemy tutaj mówić o tych, co do których istnieją dokumenty naszych poprzedników, ani o tych, którzy od niepamiętnego czasu czczeni są jako błogosławieni" "

Najważniejszym i najczęstszym w praktyce okazał się przypadek

4 Tekst obu aktów papieża Urbana VIII został przedrukowany w: Codex pro postulatoribus. Edd. La uri, Fornari, Santarelli, Roma ${ }^{4} 1929$ s. 283-286.

5 Tamże, s. 284.

"Szerzej na temat ,wypadku wyjętego" zob.: J. Bros c h, Der Heiligsprechungsprozess per viam cultus, Roma 1938, s. 15-78. 
niepamiętnego kultu. O ile $\mathrm{w}$ sprawach zwyczajnych przewidziany był przez Urbana VIII proces na temat braku kultu (de non cultu), to $\mathrm{w}$ sprawach ,wypadku wyjętego" należało przede wszystkim przeprowadzić postępowanie stwierdzające istnienie legalnego kultu publicznego i ewentualnie uzyskać konfirmację odnośnego dekretu ordynariusza przez Stolicę Apostolską. Proces ten rozpoczynał ordynariusz miejsca własną powagą, czyli na podstawie władzy zwyczajnej. Najważniejszym pytaniem $\mathrm{w}$ takim procesie było zagadnienie powstania kultu niepamiętnego, to jest określenia jego początku. Musiał on sięgać przynajmniej sto lat przed wydaniem konstytucji Caelestis Hyerusalem cives (1634), czyli przed rok 1534. Do ordynariusza miejsca należało prawo stwierdzenia legalności kultu, czyli jego zgodności z przepisami Urbana VIII (chodziło o czas powstania kultu i uzasadnienie tytułu przewidzianego w dekretach). Ordynariusz też wydawał dekret legalności kultu. Jeżeli on zaniedbał wydania dekretu, a sprawa została przekazana do zatwierdzenia, to Stolica Apostolska zwracała uwage ordynariuszowi na konieczność wydania stosownego dekretu legalności kultu. Dla przykładu, w sprawie bł. Kingi biskup krakowski nie wydał dekretu aprobującego „wypadek wyjęty”, wówczas Kongregacja Obrzędów 23 III 1666 r. nakazała zadośćuczynić wymogom prawa ${ }^{7}$.

Ordynariusz mógł poprzestać na stwierdzeniu legalności kultu i nie starać się o jego zatwierdzenie, tj. beatyfikację równoznaczną. W wypadku zwykłej kontynuacji kultu publicznego, który od lat był oddawany słudze Bożemu, zdaniem Benedykta XIV - opierającego się na postanowieniach Soboru Trydenckiego - nie trzeba było prowadzić procesu o „wypadku wyjętym”, ale wystarczal dekret ordynariusza stwierdzający legalność tegoż kultu ${ }^{8}$.

Znany kanonista De Matta napisał w 1678 r., że dekret ordynariusza tylko wtedy nie wymaga zatwierdzenia przez Stolicę Apostolską, gdy chodzi o kontynuację kultu lub jego odnowienie, ale wymaga zatwierdzenia, gdy sprawa zdąża do kanonizacji ${ }^{9}$. Podobnie też kanon 2125 Kodeksu z r. 1917 mówił o możliwości (peti potest), a nie konieczności za-

Największym znawcą procedury ustanowionej przez Urbana VIII dla „wypađku wyjętego" był Prosper Lambertini, stąd jego komentarz jest rozstrzygający w naszej sprawie. Zob.: P. Lambertini, De Servorum Dei beatificatione et canonizatione Beatorum I 31, 3, Boloniae 1734, s. 246.

${ }_{8}$ Canones et decreta Concilii Tridentini, Taurini 1913, s. 207: „Sessio XXV De invocatione, veneratione et reliquiis sanctorum: [...] statuit sancta "Synodus nemini licere ullo in loco vel ecclesia etiam quomodiolibet exepta ullam insolitam ponere vel ponendam curare imaginem, nisi ab episcopo probata fuerit, nulla etiam admittenda esse miracula, nec novas reliquias recipiendas, nisi eodem recognoscente et approbante episcopo".

"Zob. jego 23. rozdział w: Novissimus de Sanctorum canonizatione tractatus in quinque partes divisus [...], Romae 1678. 
twierdzenia kultu przez Stolicę Apostolską, gdy się nie dąży do kanonizacji.

Wydaje się rzeczą wskazaną dodać tu jeszcze uwagi na temat odnowienia zaniedbanego kultu publicznego. Otóż za papieża Klemensa XIII (1758-1769) biskup Syrakuz Józef Antoni zwrócił się do Stolicy Apostolskiej w sprawie zaniedbanego kultu bł. Fryderyka Campisanusa. Klemens XIII w dekrecie z 16 VIII 1763 r. polecił, aby biskup ,ordinaria auctoritate" zebrał publiczno-prawne dowody kultu. Powinien wykazać $\mathrm{w}$ tym postępowaniu, prowadzonym własną powagą, że błogosławiony był czczony przynajmniej przez okres stu lat przed dekretami Urbana VIII, tj. od r. 1534. W wypadku pozytywnego rezultatu dochodzenia biskup mógł restytuować kult zaniedbany i porzucony.

Przepisy tego dekretu, jak i poprzednio wspomnianych, obowiązują do dzisiaj, gdyż nie zostały żadnymi aktami papieskimi zniesione ani odwołane ${ }^{10}$.

W odniesieniu do bł. Michała Giedroycia z punktu widzenia przepisów prawnych interesują nas $\mathrm{w}$ zagadnieniu stwierdzenia legalności kultu pewne problemy, które zależą od naukowych ustaleń historyków. I tak stwierdzenie początku kultu publicznego i jego terytorialnego zasięgu zależy od naukowego zweryfikowania dawnych życiorysów błogosławionego. Chodzi o datę powstania i ewentualnie treść pierwszego życiorysu błogosławionego, który to życiorys spłonął prawdopodobnie w r. 1494 lub 1528. Dalej istotne znaczenie ma naukowe opracowanie życiorysu napisanego w r. 1544 przez Jana z Trzciany, profesora Akademii Krakowskiej. Życiorys ten zawiera zeznania naocznych świadków o heroiczności cnót, o cudach i opinię świętości. Życiorys oparty o zeznania naocznych świadków, jak np. spowiednika Jana ze Żmigrodu, bywa nazywany przez specjalistów prawa kanonizacyjnego „małym procesem". Powinny być przeprowadzone także dokładne studia nad nowym żywotem, wydanym w r. 1605 przez Krzysztofa z Przeworska. Życiorys ten jest prawdopodobnie powtórzeniem życiorysu napisanego przez Jana z Trzciany. To samo dotyczy życiorysu wydanego w r. 1615 przez Andrzeja Gronowskiego i wszystkich pozostałych biografii błogosławionego. Zrozumiałą jest rzeczą, iż największe zainteresowanie w kwestii ustalenia początku kultu publicznego powinny wzbudzić życiorysy wydane przed r. 1534 oraz późniejsze, referujące stan kultu sprzed tejże daty.

$\mathrm{Z}$ punktu widzenia prawa istotne jest także dokładne opracowanie wszystkich innych dokumentów historycznych dotyczących błogosławionego i tzw. „znaków kultu”, z naukowym ustaleniem czasu ich pocho-

10 Zob. J. Bros ch, jw., s. 113-114. 
dzenia, autentyczności i znaczenia dla sprawy. Chodzi tu o źródła historyczne sprzed r. 1534: modlitewniki, nabożeństwa na jego cześć lub jemu przypisywane, grób, statuy, obrazy, tablice wotywne. W praktyce kongregacji bierze się pod uwagę także inne ,,znaki kultu”, jak np. pielgrzymki do grobu, dokumenty świeckie, psałterze lub antyfonarze ozdobione podobizną błogosławionego, dowody próśb o relikwie oraz dowody ich rozdzielania, poświęcenia ołtarzy lub kościołów słudze Bożemu, wpisy do Martyrologium rzymskiego lub martyrologiów lokalnych, imię sługi Bożego powszechnie dawane na chrzcie, obieranie za patrona miasta lub społeczności, usilne prośby - choćby bezskuteczne - o beatyfikację, nadawanie imienia sługi Bożego szkołom, instytutom, ulicom, wykopaliska świadczące o kulcie, odkrycia architektoniczne w kościołach, wyjątki z roczników, nekrologów itp. ${ }^{11}$ Zrozumiałą jest rzeczą, że dla wykazania kontynuacji kultu bierze się pod uwagę także „znaki kultu" pochodzące z okresu po r. 1534.

$\mathrm{Z}$ punktu widzenia prawa interesująca jest także kwalifikacja pierwszego i drugiego otwarcia grobu bł. Michała Giedroycia w latach 1591-1600 i 1624. Istotne jest pytanie, czy te dwie ekshumacje były przygotowaniem do beatyfikacji. Podobnie kluczowym problemem jest sprawa elewacji relikwii w r. 1625, poświęcenie ołtarza błogosławionemu, umieszczenie obrazu Michała nad jego grobowcem. Czy możemy mówić, że jeszcze wtedy elewacja miała taki walor jak w średniowieczu, tj. równała się beatyfikacji, czy może było to tylko przygotowanie do beatyfikacji, której później zaniechano wskutek surowych reguł prawa Urbana VIII? Powstaje też pytanie, czy można to nazwać tzw. „kanonizacją biskupią", czy równało się to stwierdzeniu przez ordynariusza legalności kultu publicznego.

$\mathrm{Na}$ podstawie przedstawionego materiału prawnego oraz po wzięciu pod uwage dotychczasowych danych na temat kultu bł. Michała Giedroycia, byłoby rzeczą uzasadnioną, aby dążyć najpierw do wydania formalnego dekretu biskupa diecezjalnego, stwierdzającego legalność kultu błogosławionego. W tym przedmiocie zachodziłaby analogia do dekretu wydanego ,auctoritate ordinaria” przez kard. Karola Wojtyłę 22 II 1974 r. w odniesieniu do królowej Jadwigi ${ }^{12}$.

$\mathrm{W}$ tym celu biskup diecezjalny działając pozasądowo, niejako $\mathrm{z}$ punktu widzenia naukowego, powołuje komisję historyczną w diecezji, której funkcje i zadania są już w literaturze prawniczej dostatecznie opra-

11 Tamże, s. 23-38; M. d'Al fonso, La prova in genere e la fama di santità in specie nei processi dei santi prima e dopo il. M.P. „Sanctitas clarior”, Agnesotti 1977, s. 77 n.

$12 \mathrm{Cz}$. S t a wisko, Blogosławiona Jadwiga królowa - historia jej kultu, beatyfikacja, formularze liturgiczne, Rzym 1981, s. 16. 
cowane ${ }^{18}$. Komisja by zebrała i opracowała dokumentację nie tylko odnoszącą się do początków kultu, lecz także obrazującą jego nieprzerwane trwanie aż do dzisiejszych czasów, zasięg kultu i jego przejawy. $\mathrm{Na}$ podstawie prac komisji biskup diecezjalny może wydać dekret legalności kultu publicznego, trwającego od czasów niepamiętnych, tzn. od w. $\mathrm{XV}$ do dziś.

W ten sposób przebiega pierwszy etap do beatyfikacji równoznacznej. Jeżeli powód zainteresowany pragnie sprawę kontynuować, należy starać się o konfirmację kultu publicznego przez Stolicę Apostolską.

II. KONFIRIMACJA KULTU, CZYLI BEATYFIKACJA MICHAEA GIEDROYCIA

Pierwszym istotnym wymogiem $\mathrm{w}$ dążeniu do beatyfikacji jest, według nowego prawa, zasięgnięcie opinii Konferencji Episkopatu, czy sluszne jest rozpoczynanie sprawy ${ }^{14}$. Tego samego zagadnienia dotyczy przepis Norm z 7 II 1983 r., nakładający na biskupa diecezjalnego obowiązek przesłania do Stolicy Apostolskiej krótkiej wiadomości m. in. na temat ,doniosłości sprawy” ${ }^{15}$. Chodzi tu o tzw. ,element eklezjalny” danej beatyfikacji, tj. jej duszpasterskie zapotrzebowanie i uzasadnienie. W wypadku bł. Michała chyba można by poruszyć cnotę cierpliwości tak bardzo dzisiaj potrzebną, bezgraniczne umiłowanie Ukrzyżowanego, pokutę i umartwienie równie obce dzisiejszemu człowiekowi, a jednocześnie potrzebne dla jakiejśs równowagi duchowej.

Drugim problemem w dążeniu do beatyfikacji równoznacznej, poza kwestiami już omówionymi, tj. stwierdzeniem legalności kultu, jego nieprzerwanego trwania, orzeczonego dekretem biskupa diecezjalnego, oraz poza wspomnianym elementem eklezjalnym, będzie niewątpliwie zagadnienie udowodnienia jego świętości życia, czyli heroiczności cnót. Należy tu najpierw zaznaczyć, iż beatyfikacja równoznaczna występowała $\mathrm{w}$ historii w dwóch postaciach: starej i nowej. Beatyfikacja pierwotna polegała na zwykłym zatwierdzeniu kultu publicznego, legalnie oddawanego, bez uprzedniej aprobaty cnót heroicznych, czyli bez szczegółowego badania świętości życia. Dekret Urbana VIII z 1631 r. nakazywał wprawdzie przeprowadzanie procesu informacyjnego na temat opinii świętości, tj. cnót w stopniu heroicznym i cudów, ale proces ten w sprawach kultu opuszczano, od początku poprzestając na stwierdzeniu legalności tegoż kultu j papieskiej konfirmacji. W wypadku, gdyby

13 Por. H. Misztal, Causae historicae $w$ postępowaniu beatyfikacyjnym $i k a-$ nonizacyjnym, Lublin 1981, s. 65-72.

14 Normy z 7 II $1983 \mathrm{nr} 11$ a [w:] Novae leges, jw., s. 12.

15 Tamże, s. 13. (nr $15 \mathrm{c}$ ). 
sprawa była prowadzona do kanonizacji, wtedy dopiero wysyłano by „litterae remissoriales" do procesu apostolskiego na temat cnót ${ }^{16}$.

Od papieża Piusa X (1903-1914) wymagania do beatyfikacji równoznacznej zostały zrównane $\mathrm{z}$ wymaganiami do beatyfikacji formalnej. Było to równanie wzwyż i wcale nie ułatwiło sprawom prowadzonym drogą kultu sytuacji prawnej i faktycznej. Pius $\mathrm{X}$ w dekrecie Cum in agendis z 11 XI 1912 r. wprowadził taką procedurę do beatyfikacji równoznacznej, że po zatwierdzeniu kultu przez Stolicę Apostolską należy prowadzić proces apostolski na temat cnót heroicznych. Dopiero po zatwierdzeniu kultu i aprobacie cnót sługa Boży może być beatyfikowany równoznacznie. Tego rodzaju beatyfikacja, poprzedzona także aprobatą cnót, bywa nazywana beatyfikacją równoznaczną w nowej formie ${ }^{17}$.

Dekret Piusa X Cum in agendis wywołał lawinę próśb do Stolicy Apostolskiej o dyspensę od jego wymogów i pozwolenie przynajmniej na dokończenie spraw już rozpoczętych według starej procedury. Pius X dekretem z 31 I 1913 r. Edito decreto „Cum in agendis" złagodził dyscyplinę o tyle, że w wypadku spraw kultu nie wymaga się „,constare de casu excepto" lecz ,ita constare de casu excepto ut ad ulteriora procedi possit" ${ }^{18}$. Zatem papież dopuścił możliwość w sprawach kultu łagodniejszego traktowania dowodzenia „wypadku wyjętego" i cnót heroicznych. Dla przykładu w dekrecie heroiczności cnót bł. Doroty z Mątowów czytamy: „Constare de casu excepto atque de virtutibus ita constare ut ad disceptationem super miraculis pro canonizatione quandocumque deveniri possit" ${ }^{19}$.

Istotne znaczenie dla spraw kultu i wszystkich tego rodzaju spraw dawnych miało ustawodawstwo papieża Piusa XI, zwłaszcza motu proprio pt. Già da qualche tempo z 6 II 1930 r. ${ }^{20}$ i Normae servandae in constituendis processibus ordinariis super causis historicis z 4 I 1939 $\mathrm{r}^{21}$ Dopuściło ono jako równoprawny $\mathrm{z}$ zeznaniami świadków środek dowodowy oparty na dokumentach i innych źródłach pisanych. Tymże motu proprio został utworzony w łonie Kongregacji Obrzędów organ naukowy do opracowywania pozycji historycznych mających zastąpić proces apostolski w diecezji na temat „wypadku wyjętego" i cnót heroicznych. Sekcja Historyczna, przemianowana w 1969 r. na Urząd Hi-

16 Zob. J. Bros c h, dz. cyt. s. $89-90$.

17 Sacra Rituum Congregatio. Decretum de iudiciali ordine servando in causis Saervorum Dei procedentibus per viam casus excepti, 11 XI 1912, „Acta Apostolicae Sedis" 4 (1912) s. 705-707.

18 „Acta Apostolicae Sedis” 5 (1913) s. 41-42.

19 Zob. dekret z 9 I 1976.

20 „Acta Apostolicae Sedis” 22 (1930) s. 87-88.

21 „Acta Apostolicae Sedis" 31 (1939) s. 174-176.

28 -- Analecta Cracoviensia 
storyczno-Hagiograficzny, a obecnie (1983) w Kolegium Relatorów, pomogła zakończyć szczęśliwie wiele spraw dawnych ${ }^{22}$.

Przechodząc do sprawy Michała Giedroycia, przede wszystkim podkreślić należy, iż powołana przez biskupa diecezjalnego komisja historyczna miałaby za zadanie zebrać całą dokumentację odnośnie do życia, kultu i świętości. Do niej należałaby ocena wartości historycznej zgromadzonego materiału dowodowego (autentyczność, wiarygodność, opracowanie krytyczne dokumentacji). Po otrzymaniu relacji komisji historycznej biskup diecezjalny poprzez swojego delegata lub postulatora diecezjalnego musiałby odpowiedzieć sobie na zasadnicze pytanie, które później stawia się w kongregacji konsultorom historykom, czy zgromadzona dokumentacja jest wystarczająca do ułożenia pozycji na temat kultu i cnót, tj. czy jest wystarczająca do przeprowadzenia dowodzenia według formuły: „Ita constare do casu excepto, ut ad ulteriora procedi possit". Gdyby na postawione pytanie padła odpowiedź pozytywna, sprawa byłaby na bardzo dobrej drodze.

Jeśli natomiast biskup diecezjalny, jego delegat lub postulator wyczuwałby, iż materiał dowodowy jest zbyt skąpy (jak to miało miejsce np. przy sprawie kanonizacyjnej bł. Wincentego Kadłubka), to należałoby pomyśleć o uzyskaniu dyspensy od prowadzenia sprawy według drogi przewidzianej przez Piusa $\mathrm{X}$, tj. bez pełnego udowodnienia cnót. Dla przykładu taka dyspensa była uzyskana w sprawie bł. Bogumiła. Biskupi polscy usilnie prosili, aby zastosować starą procedurę konfirmacii kultu, tj. bez aprobaty cnót. Taką dyspensę uzyskali w dniu 11 VIII 1920 od papieża Benedykta XV. Wtedy wskutek licznych listów postulacyjnych $\mathrm{z}$ Polski głosowanie $\mathrm{w}$ kongregacji nad sprawą zatwierdzenia kultu bł. Bogumiła w dniu 19 V 1925 r. dało wynik pozytywny. Dekret kongregacji zatwierdził papież Pius XI 27 V 1925 r. według starej formy przedkodeksowej, tj. bez aprobaty cnót bł. Bogumiła ${ }^{23}$. W pewnym sensie proces beatyfikacyjny bł. Bogumiła może służyć jako analogiczny przykład dla sprawy bł. Michała Giedroycia ${ }^{24}$.

Podobnie, jak już to zostało wspomniane, pewna analogia zachodzi pomiędzy sprawą Michała Giedroycia i bł. królowej Jadwigi. Kongregacja Spraw Kanonizacyjnych na sesji odbytej 25 V 1979 r. poddała dyskusji urzędową relację o kulcie bł. Jadwigi. Jeśli istotnie - jak pisze jeden $\mathrm{z}$ autorów - „w wyniku dyskusji ustalono casus exceptus, czyli istnienie kultu publicznego bł. Jadwigi królowej przed 1534 r." ${ }^{25}$,

22 Zob. H. M is z t a 1, jw., s. 48-60.

23 Decretum Vladislaviensis confirmationis cultus, Typis Polyglottis Vaticanis 27 V 1927; „Acta Apostolicae Sedis" 17 (1925) s. 384-387.

${ }_{24}$ Zob. Proces beatyfikacyjny $i$ kanonizacyjny arcybiskupa Bogumita $w$ XVII wieku wedtug rękopisu Ossolineum 220 II, wyd. B. Bolz, Poznań 1982.

$25 \mathrm{Zob} . \mathrm{Cz}$. St a w is k o, jw., s. 18. 
to było ono czymś na sposób beatyfikacji równoznacznej w starej formie, tj. beatyfikacji bez przeprowadzonej aprobaty cnót heroicznych. Wydaje się jednak, że w tym wypadku zachodził wypadek szczególny i należy go traktować jako wyjątkowy. W wypadku bł. Michała należałoby po przeprowadzeniu solidnych badań inistorycznych na forum diecezjalnym dążyć do przygotowania urzędowej pozycji o jego życiu, kulcie i cnotach heroicznych.

Osobnym zagadnieniem w dążeniu do beatyfikacji jest sprawa aprobaty przynajmniej jednego cudu zdziałanego za przyczyną sługi Bożego i udowodnienia opinii znaków cudownych ${ }^{26}$. Obecnie nie obowiązuje już przepis Kodeksu Prawa Kanonicznego z r. 1917, dotyczący liczby cudów wymaganych do beatyfikacji (kan. 2127). Wymogi prawa są obecnie jednoznaczne, choć praktyka kongregacji zna wypadki udzielania dyspens ${ }^{27}$.

\section{UZYSKANIE ZEZWOLEŃ NA MSZE I OFICJUM WEASNE}

O BEOGOSEAWIONYM

Już papież Leon XII (1823-1829) w dekrecie z 20 XII 1826 r. Ad tollendos et eliminandos abusus przypomniał postanowienia papieża Urbana VIII i Benedykta XIV oraz dwuwiekową tradycję, iż uzyskanie zezwoleń Stolicy Apostolskiej na msze i oficjum własne o błogosławionym możliwe jest dopiero po beatyfikacji. To postępowanie zostało W praktyce zaniedbane i dlatego celem dekretu Leona XII było jego przywrócenie. Często obierano prostszą drogę i proszono o pozwolenie na msze i oficjum własne, aby na tym poprzestać. Leon XII postanowił, iż w sprawie wspomnianych indultów należało otworzyć oddzielną instancję po zatwierdzeniu kultu ${ }^{23}$. Taka praktyka kongregacji trwa do dzisiaj, skoro tak też postąpiła Kongregacja Kultu Éożego w sprawie bł. Jadwigi królowej; - jak pisze jeden $\mathrm{z}$ autorów - mając bowiem decyzję Kongregacji Spraw Kanonizacyjnych (akceptującej casus exceptus) zajęła się zatwierdzeniem formularzy liturgicznych. Uczyniła to dekretem z 29 V 1979 r. ${ }^{29}$

Streszczając uwagi na temat sprawy beatyfikacyjnej bł. Michała należy przyjąć następujący porządek:

1. Dążyć do wydania przez kompetentnego biskupa diecezjalnego dekretu stwierdzającego legalność kultu zgodnie z przepisami Urbana

${ }_{26}$ Zob. art. 26 § 1: Sacra Congregazione per le Cause dei Santi. Regolamento della Sacra Congregazione per le Cause dei Santi, Roma 1983, s. 14.

27 Zob. H. M is z t a l. jw., s. $103-106$.

${ }_{28}$ Zob. tekst dekretu w: Codex pro postulatoribus, jw., s. 308-310.

29 Zob. Cz. S t a w is k o, jw., s. 18. 
VIII. W tym celu zainteresowany powód po uzasadnieniu ważności sprawy poprzez swojego urzędowego przedstawiciela (postulatora) zwraca się do biskupa diecezjalnego. Biskup sam lub przez swego delegata powoluje na razie komisję historyków do badań naukowych na temat początków kultu i jego dokumentacji. Wyniki badań komisji, przedstawione w odpowiedniej relacji, posłużą biskupowi do podjęcia decyzji odnośnie do wydania dekretu legalności kultu.

2. W wypadku, gdyby zebrany przez komisję i postulację materiał dowodowy okazał się zdaniem ekspertów od spraw beatyfikacyjnych wystarczający do ułożenia odpowiedniej pozycji o życiu, kulcie i cnotach sługi Bożego, można wystąpić do Stolicy Apostolskiej z prośbą o zatwierdzenie kultu, a w konsekwencji o beatyfikację równoznaczną. Opracowanie pozycji historycznej należy już do Kongregacji Spraw Kanonizacyjnych, która wyznacza do tej czynności odpowiedniego relatora.

3. Zatwierdzenie formularzy liturgicznych i udzielenie innych indultów Stolicy Apostolskiej, rozszerzających dotychczasowy kult publiczny, powinno nastąpić dopiero po beatyfikacji.

\title{
BEATIFICATION OF MICHAEL GIEDROYC. PROCEDURE
}

\author{
S u $\mathbf{m} \mathbf{m}$ a $\mathbf{r} \mathbf{y}$
}

The local public cult of Michael Giedroyc (1st half of 15th c. - 1485), in the Church that can be observed in Krakow as well as in Lithuania, was the main motif of the symposium organized by the Rector of St Mark Church in Krakow, in order to achieve better familiarity with the life of the Blessed and also with the possibilities of further proceedings of beatification. As far as the beatification of Michael Giedroyć is concerned, there have been analysed premises allowing for such a proceeding in accordance with the canon law.

The procedure should be ordered in the following way:

1. Obtain a decree from a diocesan bishop that would ascertain legality of the cult, according to the instructions of pope Urban VIII. Therefore, a comission of skillful historians should be called, who would examine documents referring to the public cult from its origin up to now. The results of such investigations should help the bishop in making decision about a decree concerning the legality of the cult.

2. In case the gathered material will be considered by the experts of canonization as being sufficient in proving holiness of life of Michael Giedroyć, it is possible to apply for confirmation of the cult to the Holy See.

3. The next step, after a formal beatification, can aim at obtaining other indults, i.e. proper Office and Mass of the Blessed. 